\title{
JURNAL TEKNOLOGI LABORATORIUM
}

(www.teknolabjournal.com)

Vol.6, No.1, Maret 2017, pp. $25 \sim 30$

ISSN: 2338 - 5634 (print); ISSN: 2580-0191 (online)

Received : 13-03-2017; Revised : 29-03-2017 ; Accepted : 25-04-2017

\section{Uji Antibakteri Ekstrak Metanol Kulit Buah Manggis (garcinia mangostana I.) Terhadap Staphyllococcus aureus dan Escherechia coli}

\author{
Sujono ${ }^{1^{*}}$, Anik Nuryati ${ }^{2}$ \\ 1,2 Jurusan Analis Kesehatan Poltekkes Kemenkes Yogyakarta \\ Jln. Ngadinegaran MJ III/62 Yogyakarta \\ Corresponding author email: sujono_analis@yahoo.co.id
}

\begin{abstract}
Alfa mangostin, gamma-mangostin and xanthone group compounds are secondary metabolites contained in mangosteen (G. mangostana $L$.) which can be isolated from the fruit, bark, leaves and rind of mangosteen. All three compounds were shown to inhibit stronger against Mycobacterium tuberculosis. Alfa mangostin also active against Staphylococcus aureus and Enterococcus bacteria that are resistant to vancomisin and methicillin. Objective of this study to determine the antibacterial activity of methanol extract of mangosteen rind against Staphyllococcus aureus and Escherechia coli in vitro.

Antibacterial activity test used is the diffusion wells and paper disc diffusion method. The test results obtained antibacterial activity of methanol extract of mangosteen rind can inhibit the growth of Staphyllococcus aureus at a concentration of $16 \%$, but below its resistance zone diameter Cyprofloxacin. As against Escherichia coli, the methanol extract of mangosteen rind could not inhibit the growth of bacteria.
\end{abstract}

Keywords: Antibacterial; Escherichia coli; Mangosteen; Staphylococcus aureus

(C) 2017 Jurnal Teknologi Laboratorium

\section{Pendahuluan}

Sejak jaman dahulu masyarakat Indonesia sudah mengenal dan menggunakan tumbuhan berkhasiat obat sebagai salah satu upaya penanggulangan masalah kesehatan yang dihadapi. Hal ini telah dilakukan jauh sebelum pelayanan kesehatan formal dengan obat-obatan modern menyentuh masyarakat. Pengetahuan tentang tumbuhan obat merupakan warisan budaya bangsa secara turun temurun.[1]

Kulit buah manggis mengandung senyawa xanton terprenilasi, alfa mangostin, gamma-mangostin dan garsinon B. Senyawa xanton terprenilasi yang diisolasi dari kulit buah manggis, telah dibuktikan sebagai anti mikroorganisme yaitu sebagai antituberkulosa. Alfa mangostin, gamma-mangostin dan garsinon B juga menunjukkan mampu menghambat terhadap bakteri Mycobacterium tuberculosis.[2]

Kandungan alfa mangostin juga aktif terhadap bakteri Enterococci dan Staphylococcus aureus yang masing-masing resisten terhadap vancomisin dan metisilin. Ini diperkuat dengan aktivitas sinergisme dengan beberapa antibiotika (gentamisin dan vancomisin) terhadap kedua bakteri tersebut. Alfa mangostin juga

Uji Antibakteri Ekstrak Metanol Kulit Buah Manggis ... 


\section{JURNAL TEKNOLOGI LABORATORIUM}

(www.teknolabjournal.com)

Vol.6, No.1, Maret 2017, pp. 25 30

ISSN: 2338 - 5634 (print); ISSN: 2580-0191 (online)

Received : 13-03-2017; Revised : 29-03-2017 ; Accepted : 25-04-2017

mempunyai efek antiplasmodial level menengah, sedangkan xanton terprenilasi yang mempunyai gugus alkilamino menghambat sangat poten.[3]

Banyaknya produk obat dari kulit buah manggis yang beredar di pasaran menyebabkan konsumen semakin sulit untuk memilih produk mana yang akan dibeli. Berbagai macam kandungan zat berkhasiat dalam kulit menunjukkan perbedaan pula dalam antivitasnya sebagai antioksidan, anti inflamasi, antibakteria dan anti kanker.

Keracunan makanan karena stafilokokkus disebabkan asupan makanan yang mengandung toksin stafilokokkus, yang terdapat pada makanan yang tidak tepat cara pengawetannya. Enterotoksin stafilokokus stabil terhadap panas. Gejala terjadi dalam waktu $1-6$ jam setelah asupan makanan terkontaminasi. Sekitar $75 \%$ pasien mengalami mual, muntah, dan nyeri abdomen, yang kemudian diikuti diare sebanyak $68 \%$. Masa berlangsungnya penyakit kurang dari 24 jam. Diagnosis ditegakkan dengan biakan $S$. aureus dari makanan yang terkontaminasi, atau dari kotoran dan muntahan pasien. Tidak ada peranan antibiotik dalam mengeradikasi stafilokokus dari makanan yang ditelan.[4]

EHEC (Enterohemorrhagic Escherichia coli) telah dikenal sejak terjadi wabah kolitis hemoragik. Wabah ini terjadi akibat makanan yang terkontaminasi. Kebanyakan kasus terjadi 7-10 hari setelah asupan makanan atau air terkontaminasi. EHEC dapat menjadi penyebab utama diare infeksius. Awal penyakit ditandai dengan gejala diare sedang hingga berat (10-12 kali perhari). Diare awal tidak berdarah tetapi berkembang menjadi berdarah. Antibiotik tidak efektif dalam mengurangi gejala atau resiko komplikasi infeksi EHEC.[4]

Penelitian ini bertujuan untuk mengetahui aktivitas antibakteri kulit buah manggis terhadap Staphyllococcus aureus dan Escherechia coli. Penelitian menggunakan ekstrak kulit manggis menggunakan metanol sebagai pelarut, merupakan senyawa alkohol yang paling sederhana, mudah menguap, mudah terbakar dan bersifat polar.

\section{Metode Penelitian}

Sampel berupa simplisia serbuk kulit buah manggis yang diperoleh dengan mengumpulkan serbuk kulit buah manggis dalam kemasan bermerk yang dijual di apotik. Ekstrasi menggunakan metode meserasi, karena bahan yang sudah halus memungkinkan untuk direndam dalam larutan pengekstrak sampai meresap dan melunakkan susunan sel, sehingga zat - zat yang mudah larut akan terlarut [5].

Simplisia serbuk kulit buah manggis ditambah pelarut Metanol 70\%. Larutan diaduk selama 30 menit, didiamkan 24 jam, kemudian disaring dan diulang sebanyak 2 kali. Filtrat diuapkan dengan vacuum rotary evaporator pada suhu $70 \stackrel{\circ}{\circ}$ sehingga menjadi ekstrak kental kulit buah manggis, kemudian ekstrak kental dituang dalam cawan porselin dan dipanaskan dengan waterbath suhu $70^{\circ} \mathrm{C}$ sambil terus diaduk sampai diperoleh ekstrak yang lebih kering dan beratnya tetap. Selanjutnya ekstrak metanol kulit buah manggis dibuat konsentrasi $0,5 \%$ b/v, $1 \%$ b/v, 2\% b/v, 4\% b/v, 8\% b/v, $16 \%$ b/v, 32\% b/v dan $64 \%$ b/v dengan pelarut Poly Ethylen Glikol (PEG) 5\%.

Bakteri penguji yang digunakan adalah Staphyllococcus aureus dan Escherechia coli yang diperoleh dari Balai Laboratorium Kesehatan (BLK) Yogyakarta. Uji antibakteri secara invitro dilakukan di BLK Yogyakarta dengan dua metode, yaitu metode difusi sumuran dan metode difusi kertas cakram. 


\author{
JURNAL TEKNOLOGI LABORATORIUM \\ (www.teknolabjournal.com) \\ Vol.6, No.1, Maret 2017, pp. $25 \sim 30$ \\ ISSN: 2338 - 5634 (print); ISSN: 2580-0191 (online)
}

Received : 13-03-2017; Revised : 29-03-2017 ; Accepted : 25-04-2017

\title{
2.1. Metode Difusi Sumuran [6]
}

Inokulum bakteri diinkubasi pada Mueller Hinton broth pada suhu $37^{\circ} \mathrm{C}$ selama 18 jam setelah itu diencerkan dengan $0.85 \%$ larutan $\mathrm{NaCl}$ steril sehingga mencapai kekeruhan setara dengan standar McFarland no. $0.5\left(10^{6-8} \mathrm{CFU} / \mathrm{ml}\right)$. Setiap inokulum bakteri disebarkan perlahan-lahan pada cawan petri yang berisi media Mueller Hinton agar padat dan dibuat sumuran dengan diameter $5 \mathrm{~mm}$. Sebanyak 500 mikroliter ekstrak metanol kulit buah manggis dari masing-masing konsentrasi diisikan pada tiap sumuran, dengan ulangan sebanyak empat kali. Media tersebut diinkubasikan pada suhu $37^{\circ} \mathrm{C}$ selama 24 jam, selanjutnya diukur zona penghambatan pertumbuhan bakteri disekitar sumuran. Pembanding yang digunakan adalah pelarut PEG $5 \%$ dan disk Cyprofloxacin 10 $\mathrm{gg}$.

\subsection{Metode Difusi Kertas Cakram [6]}

Inokulum bakteri diinkubasi pada Mueller Hinton broth pada suhu $37^{\circ} \mathrm{C}$ selama 18 jam setelah itu diencerkan dengan $0.85 \%$ larutan $\mathrm{NaCl}$ steril sehingga mencapai kekeruhan setara dengan standar McFarland no. $0.5\left(10^{6-8} \mathrm{CFU} / \mathrm{ml}\right)$. Setiap inokulum bakteri disebarkan perlahan-lahan pada cawan petri yang berisi media Mueller Hinton agar padat. Sebanyak 15 mikroliter ekstrak metanol kulit buah manggis dari masing-masing konsentrasi tersebut diatas diteteskan pada kertas cakram steril. Kertas cakram steril yang telah ditetesi dengan ekstrak etanol kulit buah manggis diletakkan pada permukaan media Mueller Hinton Agar (MHA) yang telah diinokulasi dengan isolat bakteri, menggunakan pinset steril. Masing-masing konsentrasi dilakukan empat kali pengulangan, media tersebut diinkubasikan pada suhu $37^{\circ} \mathrm{C}$ selama 24 jam, kemudian diukur zona penghambatan pertumbuhan bakteri disekitar sumuran. Pembanding yang dgunakan adalah pelarut PEG 5\% dan disk Cyprofloxacin 10 $\mathrm{gg}$.

\subsection{Analisis Data}

Data yang diperoleh disajikan dalam bentuk grafik zona hambatan untuk menentukan kadar hambatan minimal. Data diameter zona hambatan terhadap pertumbuhan Staphyllococcus aureus atau Escherechia coli, apabila berdistribusi normal diuji dengan Independent Sample $t$ Test atau Anova One Way dan apabila berdistribusi tidak normal diuji dengan Mann Whitney $U$ atau Kruskal Wallis Test.

\section{Hasil Dan Pembahasan}

Hasil pengukuran diameter zona hambatan ekstrak metanol kulit buah manggis terhadap Staphyllococcus aureus dan Escherechia coli didapatkan data seperti pada grafik sebagai berikut: 


\section{JURNAL TEKNOLOGI LABORATORIUM}

(www.teknolabjournal.com)

Vol.6, No.1, Maret 2017, pp. 25 30

ISSN: 2338 - 5634 (print); ISSN: 2580-0191 (online)

Received : 13-03-2017; Revised : 29-03-2017 ; Accepted : 25-04-2017

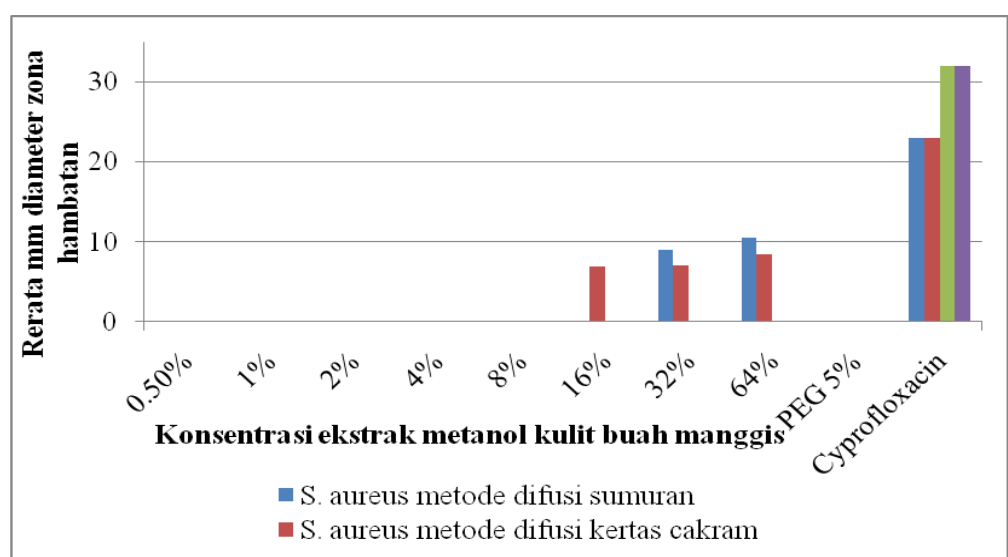

Gambar 1. Grafik Rerata diameter zona hambatan pertumbuhan Staphyllococcus aureus dan Escherechia coli dengan ekstraks metanol kulit buah manggis.

Konsentrasi minimal ekstrak metanol kulit buah manggis yang dapat menghambat pertumbuhan Staphyllococcus aureus pada metode difusi sumuran adalah $32 \%$ dengan rerata zona hambatan $9 \mathrm{~mm}$, sedangkan pada metode difusi kertas cakram adalah $16 \%$ dengan rerata zona hambatan $6,7 \mathrm{~mm}$. Ekstrak metanol kulit buah manggis tidak menunjukkan hambatan pertumbuhan Escherechia coli sampai dengan konsentrasi $64 \%$.

Hasil tersebut menunjukkan bahwa ekstraks metanol kulit buah manggis mempunyai aktivitas antibakteri terhadap Staphyllococcus aureus, tetapi tidak mempunyai aktivitas antibakteri terhadap Escherechia coli. Dibanding obat standar Cyprofloxacin dengan diameter zona hambatan $23 \mathrm{~mm}$, kemampuan ekstraks metanol kulit buah manggis kurang efektif dalam menghambat pertumbuhan Staphyllococcus aureus.

Semakin bertambah konsentrasi metanol kulit buah manggis semakin bertambah diameter zona hambatan $(z=-2,494$ dan $p=0,013)$, dan pada metode difusi kertas cakram $\left(x^{2}=9,415\right.$ dan $\left.p=0,009\right)$.

Ekstraks metanol kulit buah manggis mempunyai aktivitas antibakteri terhadap Staphyllococcus aureus, tetapi tidak dapat menghambat pertumbuhan Escherechia coli. Hasil penelitian ini tidak berbeda dengan hasil penelitian menggunakan ektrasks etanol.[7] Dinding sel bakteri Staphylococcus aureus dan bakteri gram positif lainnya, mempunyai peptidoglikan dan asam teikhoat yang sederhana. Sedangkan pada Escherichia coli memiliki lapisan peptidoglikan, lipoprotein, dan polisakarida yang komples. Pembungkus luar atau selaput dari Escherichia coli memiliki fungsi menolak molekul hidrofobik sekaligus hidrofilik dengan baik, dan jika dari molekul zat yang besar tidak akan dapat masuk ke dalam bakteri ini, sedangkan zat yang memiliki molekul kecil dapat masuk kedalam bakteri Escherichia coli. Perbedaan antara zona radikal menyebabkan Escherichia coli lebih resisten.[6]

Xanton merupakan senyawa kimia dengan manfaat antibakteri yang cukup kuat dan memiliki kemampuan memperlambat replikasi sel pada bakteri serta sebagai antioksidan yang tinggi di kulit buah manggis.[8] Saponin berfungsi sebagai antibakteri dengan jalan menghambat stabilitas dari membran sel tubuh bakteri sehingga 


\author{
JURNAL TEKNOLOGI LABORATORIUM \\ (www.teknolabjournal.com) \\ Vol.6, No.1, Maret 2017, pp. $25 \sim 30$ \\ ISSN: 2338 - 5634 (print); ISSN: 2580-0191 (online)
}

Received : 13-03-2017; Revised : 29-03-2017 ; Accepted : 25-04-2017

menyebabkan sel bakteri hancur. Mekanisme kerja saponin termasuk dalam kelompok antibakteri yang berfungsi meningkatkan tegangan permukaan pada dinding sel bakteri. Dinding sel akan mengalami peregangan yang sangat kuat dan kemudian mengakibatkan kerusakan membran sel yang pada akhirnya menyebabkan keluarnya berbagai komponen penting untuk pertahanan hidup bakteri yaitu protein, asam nukleat, dan nukleotida.[9]

Flavonoid merupakan sebuah senyawa polar yang mudah larut dalam pelarut polar seperti etanol, metanol, butanol dan aseton. Flavonoid merupakan golongan terbesar dari senyawa fenol yang mempunyai sifat sangat aktif memperlambat pertumbuhan dari virus, bakteri, dan jamur. Senyawa kimia flavonoid pada umumnya bersifat antioksidan dan banyak yang telah dimanfaatkan sebagai salah satu komponen bahan baku dalam pembuatan obat-obatan.[10]

Konsentrasi ekstraks metanol kulit buah manggis yang mampu menghambat pertumbuhan Staphyllococcus aureus adalah 16\% dan kurang sensitif dibanding obat standar Cyprofloxacin. Hal ini membuktikan bahwa ekstraks metanol kulit buah manggis tidak dapat digunakan sebagai antibakteri atau untuk pengobatan penyakit infeksi yang disebabkan oleh bakteri. Dengan bukti ini diharapkan masyarakat tidak menggunakan ekstraks kulit buah manggis sebagai obat alternatif untuk penyakit infeksi yang disebabkan bakteri.

Pemilihan uji antibakteri untuk membuktikan konsentrasi daya hambat obat herbal perlu memperhatikan kepekaan metode yang dipakai. Pada penelitian ini terbukti bahwa metode difusi kertas cakram lebih peka dibanding metode difusi sumuran. Sehingga metode yang dipilih untuk uji antibakteri sebaiknya menggunakan metode difusi kertas cakram.

\title{
4. Kesimpulan Dan Saran
}

Ekstraks metanol kulit buah manggis mempunyai aktivitas antibakteri terhadap Staphyllococcus aureus, tetapi tidak terhadap Escherechia coli, sehingga dapat dijadikan sebagai salah satu bahan sebagai antibakteri.

\section{Ucapan Terima Kasih}

Penulis mengucapkan terimakasih kepada Poltekkes Kemenkes Yogyakarta atas dukungan dana BOPTN pada DIPA Tahun 2016.

\section{Daftar Pustaka}

[1]. Muhlisah, F., 2002, "Tanaman Obat Keluarga”, Jakarta, Penebar Swadaya.

[2]. Suksamrarn, S., Komutiban, O., Ratananukul, P., Chimnoi, N., Lartpornmatulee, N. \& Suksamrarn, A. 2006, "Cytotoxic prenylated xanthones from the young fruit of Garcinia mangostana”. Chemical \& Pharmaceutical Bulletin. 54: 301-305 


\section{JURNAL TEKNOLOGI LABORATORIUM}

(www.teknolabjournal.com)

Vol.6, No.1, Maret 2017, pp. $25 \sim 30$

ISSN: 2338 - 5634 (print); ISSN: 2580-0191 (online)

Received : 13-03-2017; Revised : 29-03-2017 ; Accepted : 25-04-2017

[3]. Mahabusarakam W., Kuaha K., Wilairat P., \& Taylor W.C.., 2006, "Prenylated anthones as potential antiplasmodial substances", Planta Med., 72(10):912-916.

[4]. Procop, G.W., \& Cockerill, F.. Enteritis Caused by Escherichia coli \& Shigella \& Salmonella Species. In: Wilson WR, Drew WL, Henry NK,et al, Editors. Current Diagnosis and Treatment in Infectious Disease, New York: Lange Medical Books, 2003. $584-66$.

[5]. Ansel, H.C., 1989, Pengantar Bentuk Sediaan Farmasi, diterjemahkan oleh Farida Ibrahim, Asmanizar, lis Aisyah, Edisi keempat, 255-271, 607-608, 700, Jakarta, UI Press

[6]. Brooks, G.F., Janet, S.B., Sthephen A.M. Jawetz, Melnick and Adelbergs, 2007. "Mikrobiologi Kedokteran." Edisi 23, Alih Bahasa Oleh Mudihardi, E., Kuntaman, Wasito, E.B., Mertaniasih, N.M., Harsono, S., dan Alimsardjono, L. Penerbit Buku Kedikteran EGC. Jakarta.

[7]. Romas, A., Rosyidah, D.U., \& Aziz, M.A., 2015. "Uji Aktivitas Antibakteri Ekstrak Etanol Kulit Buah Manggis (Garcinia mangostana I) Terhadap Bakteri Escherechia coli ATCC 11229 dan Staphyllococcus aureus ATCC 6538 Secara In Vitro". University Research Colloquium 2015. 127-131

[8]. Joffrion, D.E. 2007. Mangosteen the Xfactor. Cross Oaks Chiropractic Health and Pain Relief Center. USA.

[9]. Noorhamdani, A.S., Endang, A., irwanto, A.R. 2013. “Uji Efektivitas Ekstrak Etanol Kulit Buah Manggis (Garcinia mangostana I) Sebagai Antibakteri Terhadap Acinetobacter baumannii Secara In Vitro". Jurnal Kedokteran Brawijaya. pp. 29(11): 1-13.

[10]. Naim, R.2005. Senyawa Antimikroba dari Tanaman. Bogor : IPB. 